\title{
Effect of Salicylic Acid and Potassium Nitrate on Growth and Yield of Lentil (Lens culinaris L.) under Rainfed Condition
}

\author{
Bibek Laishram $^{1}$, T. Basanta Singh ${ }^{2 *}$, Athokpam Kalpana ${ }^{1}$, \\ Merinda Wangkheirakpam ${ }^{1}$, Sunil Kumar Chongtham ${ }^{3}$ and W. Jiten Singh ${ }^{4}$
}

\author{
${ }^{1}$ Pandit Deen Dayal Upadhyay Institute of Agricultural Sciences, Utlou, \\ Bishnupur, Manipur, India \\ ${ }^{2}$ ICAR Research Complex for NEH Region, Manipur Centre, Lamphelpat, Imphal West, India \\ ${ }^{3}$ Multi Technology Testing Centre and Vocational Training Centre, CAU (Imphal), Ranipool, \\ Gangtok, Sikkim, India \\ ${ }^{4}$ Krishi Vigyan Kendra, Wangbal, Thoubal, Manipur, India
}

*Corresponding author

\section{A B S T R A C T}

\section{Keywords}

Lentil, Potassium nitrate, Salicylic acid, Seed priming

Article Info

Accepted:

20 October 2020

Available Online:

10 November 2020
A field experiment was conducted at Agricultural Research Farm, Pandit Deen Dayal Upadhyay Institute of Agricultural Sciences, Utlou, Bishnupur District, Manipur, India during the year 2018-2019 to study the effect of salicylic acid and potassium nitrate on growth and yield of lentil under rainfed condition. Seed priming with salicylic acid (200 ppm) enhanced the plant height, number of branches, fresh and dry weight and number of nodules per plant and yield attributes namely number of pods per plant and seeds per pod. Foliar spray of $\mathrm{KNO}_{3}(2.0 \%)$ foliar application significantly enhanced the growth attributes of lentil for all the growth stages except for 30 days after sowing (DAS). Yield attributes namely number of pods per plant, number of seeds per pod and yield of lentil increased significantly by application of $\mathrm{KNO}_{3}(1.5 \%)$. The treatment combination of salicylic acid (200 ppm) and $\mathrm{KNO}_{3}(1.5 \%)$ gave the maximum grain yield (1104.88 $\left.\mathrm{kg} / \mathrm{ha}\right)$, stover yield $(1799.06 \mathrm{~kg} / \mathrm{ha})$ and biomass yield $(2903.95 \mathrm{~kg} / \mathrm{ha})$. It can be inferred that seed priming of salicylic acid $(200 \mathrm{ppm})$ and foliar application of potassium nitrate $(2.0 \%$ and $1.5 \%$ ) increases the growth and yield of lentil.

\section{Introduction}

Pulses are among the most important crops which are considered as substitutes for animal protein among the vegetarian population and it also occupy special place in diets of the Indian population. They are known to render significant impact on soil health and considered to be key component for sustainable agriculture. Pulses have the capacity to fix the soil atmospheric nitrogen in their root system, which enables the plants to meet the nitrogen requirement on its own. Lentil is one of the major rabi pulses in India which contributes about $6 \%$ of the total area under pulse as well as production in India. It 
is cultivated in 3.3 million hectares with a production of about 3.1 million tonnes (Singh et al., 2011). In Manipur lentil cultivation has been increasing from the last 3-4 years in Manipur. The HUL-57 is a popular variety of lentil that has been grown successfully under rainfed conditions. This variety is adapted to cool growing conditions and it is found to be tolerant to frost.

Salicylic acid (SA) is an endogenous plant hormone that has been found to play a major role in the regulation of plant growth and development, including seed germination, organ differentiation, stomatal movement, photoperiodic responses, and senescence mediation (Raskin, 1992; Hayat et al., 2010). It has been reported to mitigate the deleterious effects of several environmental stresses on plants including low temperature and chilling (Korkmaz et al., 2007; Horvath et al., 2007), high temperature and drought (Senaratna et al., 2000), and salinity (Yildirim et al., 2008), increase tolerance and defence to pathogen attack (Raskin et al., 1990). Further, it exerts enhancement in rate and percentage of germination and seedling emergence which ensures proper crop stand under a wide range of environmental conditions (Yadav et al., 2018).

Potassium nitrate $\left(\mathrm{KNO}_{3}\right)$ is a chemical which can impact on growth, amount of nitrate, its reduction and assimilation in plants. Potassium deficiency reduces the photosynthetic $\mathrm{CO}_{2}$ fixation and transport and utilization of assimilates. Membrane and chlorophyll degradation are common in potassium deficient plants. Foliar application of potassium can also be considered as one of the alternative in order to reduce such problems. Foliar application of nutrients may result in economic use of fertilizer by virtue of reducing loss through different processes and supplying nutrients instantly to the crop. Under the moisture stress conditions, application of potassium may be considered as one promising option as it influences the water economy and crop growth, through its effect on water uptake, root growth, maintenance of turgor, transpiration and stomatal behaviour (Hsiao and Lauchi, 1986). Considering the above facts, an experiment has planned to study the effect of salicylic acid and potassium nitrate on growth and yield of lentil under the rainfed condition of Manipur.

\section{Materials and Methods}

A field experiment was conducted during the year 2018-2019 at Agricultural Research Farm, Pandit Deen Dayal Upadhyay Institute of Agricultural Sciences, Utlou, Bishnupur District, Manipur, India (Latitude: $24.72^{\circ} \mathrm{N}$ and Longitude: $93.86^{\circ} \mathrm{E}$ ). The texture, $\mathrm{pH}, \mathrm{EC}$ and organic carbon of the experimental soil were respectively, clay, $5.5,0.4 \mathrm{dS} / \mathrm{m}$ and $1.0 \%$. The available $\mathrm{N}, \mathrm{P}$ and $\mathrm{K}$ of the soil were $314.0 \mathrm{~kg} / \mathrm{ha}, 47.0 \mathrm{~kg} / \mathrm{ha}$ and $269.0 \mathrm{~kg} / \mathrm{ha}$ respectively. The study was laid out in factorial randomized block design (FRBD) with two factors i.e., seed priming with Salicylic acid $\left(\mathrm{S}_{0}\right.$ : No application, $\mathrm{S}_{1}: 150$ ppm, and $\mathrm{S}_{2}: 200 \mathrm{ppm}$ ) as Factor 1 and foliar application of Potassium Nitrate $\left(\mathrm{K}_{0}\right.$ : No application, $\mathrm{K}_{1}: \mathrm{KNO}_{3} @ 1.5 \%$, and $\mathrm{K}_{2}$ : $\mathrm{KNO}_{3} @ 2.0 \%$ ) with four replications and nine treatments. The lentil variety HUL-57 was sown in line with seed rate of $45 \mathrm{~kg} / \mathrm{ha}$. Foliar application of $\mathrm{KNO}_{3}$ was scheduled in splits by targeting the active growth stages. Biometric parameters namely plant height, number of branches, fresh and dry weight were recorded periodically at 30,60 and 90 DAS and at harvest. Number of nodules was recorded at 60 and 90 DAS. Yield attributing parameters like number of pods per plant, number of seeds per pod and test weight were recorded at harvest. Grain and straw yields were recorded plot wise and then expressed as $\mathrm{kg} / \mathrm{ha}$. To compare the effect of SA and $\mathrm{KNO}_{3}$ 
on growth and yield of lentil, data were statistically analyzed following Gomez and Gomez (1984). The statistical differences of the data generated for each character were tested with least significant difference (LSD) at $5 \%$ probability level using analysis of variance technique (ANOVA). The standard error of means (SEm \pm ) and critical difference (CD) at 5\% level of significance were calculated to compare the treatment means. To observe the significance of differences between the treatments, the mean values were compared by the Duncan's Multiple Range Test (DMRT) at probability <0.05 using SPSS software (Version 16.0). The means for groups in homogeneous sets are displayed with similar letters.

\section{Results and Discussion}

\section{Growth of lentil}

\section{Plant height}

The plant height increased with the increasing levels of salicylic acid (SA) (Table 1). The plant heights for the control plot were lowest as compared with the plots where seed priming was done with salicylic acid which recorded to be $4.90 \mathrm{~cm}, 11.96 \mathrm{~cm}, 22.01 \mathrm{~cm}$ and $27.38 \mathrm{~cm}$ respectively at 30,60, 90 DAS and at harvest. The corresponding values for the plots where $200 \mathrm{ppm}$ of salicylic acid has been applied were respectively, $5.79 \mathrm{~cm}$, $14.29 \mathrm{~cm}, 28.66 \mathrm{~cm}$ and $32.94 \mathrm{~cm}$. The increased in plant height under increasing levels of salicylic acid might be due to water soluble antioxidant compound of salicylic acid which regulate the plant growth. These findings are in good lines with those obtained by Misra and Saxena (2009) and Muthulakshmi and Lingakumar (2016). The individual effect of potassium nitrate $\left(\mathrm{KNO}_{3}\right)$ on plant height was significant for all the growth stages except for 30 DAS. The plant height increased with the increasing levels of potassium nitrate. The plant heights for the control plot were lowest which recorded to be $5.19 \mathrm{~cm}, 12.25 \mathrm{~cm}, 23.58 \mathrm{~cm}$ and $28.52 \mathrm{~cm}$ respectively at $30,60,90 \mathrm{DAS}$ and at harvest. The corresponding values for the plots where $2 \%$ of potassium nitrate has been applied were respectively, $5.38 \mathrm{~cm}, 13.83 \mathrm{~cm}, 27.20$ $\mathrm{cm}$ and $32.06 \mathrm{~cm}$. The increase in plant height under increasing level of potassium nitrate might be due to the foliar application of $\mathrm{KNO}_{3}$ which have been reported better tolerance towards moisture stress and in turn might have boosted plant growth effectively. The nutrient status in the plant plays a vital role in improving the resistance of plant to stress conditions (Yadov, 2006). Similar findings have been reported by Bardhan et al., (2007).

\section{Number of branches}

The number of branches increased with the increasing levels of salicylic acid (Table 1). The number of branches for the control plot were lowest as compared with the plots where seed priming was done with salicylic acid which recorded to be $1.11,2.20,3.40$ and 3.50 respectively at 30,60, 90 DAS and at harvest. The corresponding values for the plots where 200 ppm of salicylic acid has been applied were respectively $1.79,3.99,5.33$ and 5.43 . The increased in number of branches with increasing levels of salicylic acid might be due to the role of SA in enhancing physiological and biochemical aspect which increases the number of branches effectively. These findings are in line with those obtained by Devi et al., (2011). The effect of $\mathrm{KNO}_{3}$ on the number of branches was significant for all the growth stages except for 30 DAS. The number of branches increased with the increasing levels of potassium nitrate. The number of branches for the control plot were lowest which recorded to be $1.45,2.61$, 3.89and3.92 respectively at 30, 60, 90 DAS and at harvest. The corresponding values for 
the plots where $2 \%$ of potassium nitrate $\left(\mathrm{K}_{2}\right)$ has been applied were respectively $1.49,3.59$, 4.91 and 5.09. The increase in number of branches under increasing level of potassium nitrate might be attributed to the fact that potassium enhances plant vigour and strengthens the stalk which might have resulted in better plant growth and more number of branches. Similar findings have been reported by Deotale et al., (2015).

\section{Number of branches}

Perusal of the data revealed that the fresh weight increased with the increasing levels of salicylic acid (Table 1). The fresh weight for the control plot were lowest as compared with the plots where seed priming was done with salicylic acid which recorded to be $0.44,1.18$, 5.28and6.53 g respectively at 30, 60, 90 DAS and at harvest. The corresponding values for the plots where seed priming was done with $200 \mathrm{ppm}$ of salicylic acid were respectively $0.73,2.47,6.17$ and $7.86 \mathrm{~g}$. The increase in fresh weight under increasing level of salicylic acid might be due to the growth promoting effect of SA which increased the level of cell division within the apical meristem of seedling root and caused increase in plant growth.

These findings are in lines with those obtained by Farahbakhsh (2012). The effect of $\mathrm{KNO}_{3}$ on the fresh weight was significant for all the growth stages except for 30 DAS. The fresh weight increased with the increasing levels of potassium nitrate. The fresh weight for the control plot were lowest which recorded to be $0.61,1.70,5.56$ and 6.84 $\mathrm{g}$ respectively at 30, 60, 90 DAS and at harvest. The corresponding values for the plots where $2 \%$ of potassium nitrate has been applied were respectively 0.62, 2.09, 5.99and $7.65 \mathrm{~g}$. Similar findings have been reported by Jabeen and Ahmad (2011).

\section{Dry weight}

The dry weight increased with the increasing levels of salicylic acid (Table 1). The dry weight for the control plot were lowest as compared with the plots where seed priming was done with salicylic acid which recorded to be $0.12,0.31,2.19$ and $4.21 \mathrm{~g}$ respectively at $30,60,90$ DAS and at harvest. The corresponding values for the plots where 200 ppm of salicylic acid has been applied were respectively $0.21,0.69,3.04$ and $5.12 \mathrm{~g}$. The increase in dry weight under increasing levels of salicylic acid might be due to the promotive effect of SA on morphological characters which enhanced the photosynthetic rate and also maintained the stability of membrane thereby improving the dry matter production. Similar findings were obtained by Jeyakumar et al., (2008) and Devi et al., (2011). The effect of potassium nitrate on dry weight was significant for all the growth stages except for 30 DAS. The dry weight also increased with the increasing levels of potassium nitrate. The dry weight for the control plot were lowest which recorded to be $0.16,0.45,2.46$ and $4.45 \mathrm{~g}$ respectively at 30 , 60,90 DAS and at harvest. The corresponding values for the plots where $2 \%$ of potassium nitrate has been applied were respectively $0.17 \mathrm{~g}, 0.59,2.88 \mathrm{~g}$ and $4.90 \mathrm{~g}$. The increase in dry weight under increasing level of potassium nitrate might be due to the delayed of flowering by foliar application of $\mathrm{KNO}_{3}$. As lentil being a long day plant, any delay in flowering would facilitate more dry matter production. Similar findings have been reported by Bardhan et al., (2007).

\section{Number of nodules}

The number of nodules increased with the increasing levels of salicylic acid (Table 2). The number of nodules for the control plot was lowest as compared with the plots where seed priming was done with salicylic acid 
which recorded to be 19.82 and 26.13 respectively at 60 and 90 DAS. The corresponding values for the plots where 200 ppm of salicylic acid has been applied were respectively 23.27 and 29.35 which is 17.40 $\%$ and $8.96 \%$ higher as compared with the control. The increased number of nodules under increasing levels of salicylic acid might be due to increase in the net photosynthetic rate. These findings are in lines with those obtained by Hayat et al., (2012). The individual effect of potassium nitrate on thenumber of nodules was significant for all the growth stages.

The number of nodules increased with the increasing levels of potassium nitrate and it was lowest for control plot which recorded to be 20.64 and 26.98 respectively at 60 and 90 DAS. The corresponding values for the plots where $2 \%$ of potassium nitrate has been applied were respectively 22.49 and 28.59 which is $12.32 \%$ and $5.96 \%$ higher as compared with the control. The increase in number of nodules under increasing level of potassium nitrate might be due to the stimulative effect of $\mathrm{KNO}_{3}$ in producing photosynthate sowing to increased translocation of nutrients in plants. Similar findings have been reported by Msaakpa et al., (2013).

\section{Yield attributes of lentil}

\section{Number of pods per plant}

The analysed data regarding number of pods increased with the increasing levels of salicylic acid (Table 2). The effect of seed priming with salicylic acid on the number of pods was significant. The number of pods per plant was lowest (64.71) for the control plot and heist for the treatment $S_{2}$ (72.36) which is $11.82 \%$ more than that of the control. The increase in number of podsper plant under increasing levels of salicylic acid might be due to reduced flower drop due to efficient translocation of photosynthates from source to sink. These findings are in corroboration with those obtained by Ali and Mahmoud (2013). The individual effect of $\mathrm{KNO}_{3}$ on the number of pods was significant. The number of pods increased with the increasing level of $\mathrm{KNO}_{3}$ up to $1.5 \%$. The number of pods for the control plot was lowest (66.28) and highest for $\mathrm{K}_{2}(71.31)$ which is $7.85 \%$ more than the former.

\section{Number of seeds per pod}

The number of seeds per pod increased with the increasing levels of salicylic acid (Table $2)$. The individual effect of salicylic acid on number of seeds per pod was significant.The number of seeds per pod for the control plot was lowest (1.64) and heist for $\mathrm{S}_{2}(1.72)$ which is $4.87 \%$ higher than that of control. The increase in number of seeds per pod under increasing levels of salicylic acid might be due to increased mobilization of metabolites to the reproductive sinks. Similar findings were reported by Sujatha (2001) and Khatun et al., (2016). The effect of potassium nitrate on the number of seeds per pod was significant. The number of seeds per pod statistically improved due to increasing level of $\mathrm{KNO}_{3}$ up to $1.5 \%$.

The number of seeds per pod for the control plot was lowest which recorded to be 1.66 . The corresponding values for the plots where $1.5 \%$ of potassium nitrate has been applied were 1.71 which is $3.01 \%$ more than that of the control. The increase in number of seeds per pod might be due to the foliar application of $\mathrm{KNO}_{3}$ which have active biochemical functions in plants, enzyme activation, photosynthesis and cell division that increased the number of seeds per pod. Similar findings have been reported from foliar application of $\mathrm{KNO}_{3}$ experiments conducted by Golezani et al., (2011). 
Table.1 Effect of salicylic acid and potassium nitrate on plant height (cm), number of branches, fresh and dry weight $(\mathrm{g})$ per plant of lentil

\begin{tabular}{|c|c|c|c|c|c|c|c|c|c|c|c|c|c|c|c|c|}
\hline \multirow[t]{2}{*}{ Treatment } & \multicolumn{4}{|c|}{ Plant height (cm) } & \multicolumn{4}{|c|}{ No of branches/plant } & \multicolumn{4}{|c|}{ Fresh weight/plant (gram) } & \multicolumn{4}{|c|}{ Dry weight/plant (gram) } \\
\hline & $\begin{array}{c}30 \\
\text { DAS }\end{array}$ & $\begin{array}{c}60 \\
\text { DAS }\end{array}$ & $\begin{array}{c}90 \\
\text { DAS }\end{array}$ & Harvest & $\begin{array}{c}30 \\
\text { DAS }\end{array}$ & $\begin{array}{c}60 \\
\text { DAS }\end{array}$ & $\begin{array}{c}90 \\
\text { DAS }\end{array}$ & Harvest & $\begin{array}{c}30 \\
\text { DAS }\end{array}$ & $\begin{array}{c}60 \\
\text { DAS }\end{array}$ & $\begin{array}{c}90 \\
\text { DAS }\end{array}$ & Harvest & $\begin{array}{c}30 \\
\text { DAS }\end{array}$ & $\begin{array}{c}60 \\
\text { DAS }\end{array}$ & $\begin{array}{c}90 \\
\text { DAS }\end{array}$ & Harvest \\
\hline $\mathbf{S}_{\mathbf{0}}$ & 4.90 & 11.96 & 22.01 & 27.38 & 1.11 & 2.20 & 3.40 & 3.50 & 0.44 & 1.18 & 5.28 & 6.53 & 0.12 & 0.31 & 2.19 & 4.21 \\
\hline $\mathbf{S}_{1}$ & 5.11 & 13.22 & 26.10 & 31.33 & 1.53 & 3.30 & 4.69 & 4.81 & 0.67 & 2.12 & 6.11 & 7.56 & 0.16 & 0.59 & 3.01 & 4.88 \\
\hline $\mathbf{S}_{\mathbf{2}}$ & 5.79 & 14.29 & 28.66 & 32.94 & 1.79 & 3.99 & 5.33 & 5.43 & 0.73 & 2.47 & 6.17 & 7.86 & 0.21 & 0.69 & 3.04 & 5.12 \\
\hline SEd ( $( \pm)$ & 0.11 & 0.10 & 0.14 & 0.30 & 0.05 & 0.07 & 0.07 & 0.10 & 0.02 & 0.10 & 0.14 & 0.12 & 0.01 & 0.02 & 0.19 & 0.15 \\
\hline $\mathrm{CD}(\mathrm{P}=\mathbf{0 . 0 5})$ & 0.24 & 0.20 & 0.29 & 0.62 & 0.10 & 0.15 & 0.15 & 0.20 & 0.04 & 0.22 & 0.29 & 0.24 & 0.01 & 0.05 & 0.39 & 0.30 \\
\hline & & & & & & & & & & & & & & & & \\
\hline $\mathbf{K}_{\mathbf{0}}$ & 5.19 & 12.25 & 23.58 & 28.52 & 1.45 & 2.61 & 3.89 & 3.92 & 0.61 & 1.70 & 5.56 & 6.84 & 0.16 & 0.45 & 2.46 & 4.45 \\
\hline $\mathbf{K}_{1}$ & 5.23 & 13.39 & 25.99 & 31.08 & 1.49 & 3.28 & 4.61 & 4.73 & 0.61 & 1.99 & 6.01 & 7.46 & 0.17 & 0.55 & 2.91 & 4.86 \\
\hline $\mathbf{K}_{2}$ & 5.38 & 13.83 & 27.20 & 32.06 & 1.49 & 3.59 & 4.91 & 5.09 & 0.62 & 2.09 & 5.99 & 7.65 & 0.17 & 0.59 & 2.88 & 4.90 \\
\hline SEd $( \pm)$ & 0.11 & 0.10 & 0.14 & 0.30 & 0.05 & 0.07 & 0.07 & 0.10 & 0.02 & 0.10 & 0.14 & 0.12 & 0.01 & 0.02 & 0.19 & 0.15 \\
\hline $\mathrm{CD}(\mathrm{P}=0.05)$ & $\mathrm{NS}$ & 0.20 & 0.29 & 0.62 & NS & 0.15 & 0.15 & 0.20 & NS & 0.22 & 0.29 & 0.24 & NS & 0.05 & 0.39 & 0.30 \\
\hline
\end{tabular}

$\mathrm{S}_{0}=0$ ppm Salicylic Acid, $\mathrm{S}_{1}=150 \mathrm{ppm}$ Salicylic Acid, $\mathrm{S}_{2}=200 \mathrm{ppm}$ Salicylic Acid, $\mathrm{K}_{0}=\mathrm{KNO}_{3} 0 \%, \mathrm{~K}_{1}=\mathrm{KNO}_{3} 1.5 \%, \mathrm{~K}_{2}=\mathrm{KNO}_{3} 2.0 \%$

Table.2 Effect of salicylic acid and potassium nitrate on number of nodules per plant, seeds per pod, pods per plant and test weight $(\mathrm{g})$ of lentil

\begin{tabular}{|c|c|c|c|c|c|}
\hline \multirow[t]{2}{*}{ Treatment } & \multicolumn{2}{|c|}{ Number of nodules/plant } & \multirow{2}{*}{$\begin{array}{l}\text { Number of } \\
\text { seeds/pod }\end{array}$} & \multirow{2}{*}{$\begin{array}{l}\text { Number of } \\
\text { pods/plant }\end{array}$} & \multirow[t]{2}{*}{ Test weight (g) } \\
\hline & 60 DAS & 90 DAS & & & \\
\hline \multicolumn{6}{|c|}{ Salicylic acid levels } \\
\hline $\mathbf{S}_{\mathbf{0}}$ & 19.82 & 26.13 & 1.64 & 64.71 & 20.79 \\
\hline $\mathbf{S}_{1}$ & 22.33 & 28.64 & 1.70 & 69.80 & 21.12 \\
\hline $\mathbf{S}_{2}$ & 23.27 & 29.35 & 1.72 & 72.36 & 21.21 \\
\hline SEd ( $( \pm)$ & 0.15 & 0.33 & 0.004 & 0.38 & 0.21 \\
\hline $\mathrm{CD}(\mathrm{P}=\mathbf{0 . 0 5})$ & 0.31 & 0.68 & 0.01 & 0.80 & NS \\
\hline \multicolumn{6}{|c|}{ Potassium nitrate levels } \\
\hline $\mathbf{K}_{\mathbf{0}}$ & 20.64 & 26.98 & 1.66 & 66.28 & 20.97 \\
\hline $\mathbf{K}_{1}$ & 22.29 & 28.55 & 1.71 & 71.31 & 21.05 \\
\hline $\mathbf{K}_{2}$ & 22.49 & 28.59 & 1.69 & 69.27 & 21.10 \\
\hline SEd ( \pm$)$ & 0.15 & 0.33 & 0.00 & 0.38 & 0.21 \\
\hline $\mathrm{CD}(\mathrm{P}=\mathbf{0 . 0 5})$ & 0.31 & 0.68 & 0.01 & 0.80 & NS \\
\hline
\end{tabular}

$\mathrm{S}_{0}=0$ ppm Salicylic Acid, $\mathrm{S}_{1}=150 \mathrm{ppm}$ Salicylic Acid, $\mathrm{S}_{2}=200 \mathrm{ppm}$ Salicylic Acid, $\mathrm{K}_{0}=\mathrm{KNO}_{3} 0 \%, \mathrm{~K}_{1}=\mathrm{KNO}_{3} 1.5 \%, \mathrm{~K}_{2}=\mathrm{KNO}_{3} 2.0 \%$ 
Table.3 Effect of salicylic acid and potassium nitrate on grain yield (kg/ha) of lentil

\begin{tabular}{|c|c|c|c|c|c|}
\hline \multicolumn{2}{|c|}{ Treatments } & \multicolumn{3}{|c|}{ Potassium nitrate levels } & \multirow{3}{*}{$\begin{array}{l}\text { Mean S } \\
784.80\end{array}$} \\
\hline & & \multirow{2}{*}{$\begin{array}{c}\mathrm{K}_{0} \\
723.78\end{array}$} & \multirow{2}{*}{$\begin{array}{c}\mathrm{K}_{1} \\
821.30\end{array}$} & \multirow{2}{*}{$\begin{array}{c}\mathrm{K}_{2} \\
809.32\end{array}$} & \\
\hline $\bar{\lambda} 0$ & $\mathrm{~S}_{0}$ & & & & \\
\hline$\stackrel{0}{\circ}$ & $\mathrm{S}_{1}$ & 847.16 & 946.93 & 902.08 & 898.72 \\
\hline & $\mathrm{S}_{2}$ & 883.75 & 1104.89 & 1080.09 & 1022.91 \\
\hline & Mean K & 818.23 & 957.71 & 930.49 & \\
\hline & & $\operatorname{SEd}( \pm)$ & $\mathrm{CD}(\mathrm{P}=0.05)$ & & \\
\hline & Factor $(\mathrm{S})$ & 12.33 & 25.59 & & \\
\hline & Factor (K) & 12.33 & 25.59 & & \\
\hline & Factor (S X K) & 21.35 & 44.32 & & \\
\hline
\end{tabular}

$\mathrm{S}_{0}=0$ ppm Salicylic Acid, $\mathrm{S}_{1}=150 \mathrm{ppm}$ Salicylic Acid, $\mathrm{S}_{2}=200 \mathrm{ppm}$ Salicylic Acid, $\mathrm{K}_{0}=\mathrm{KNO}_{3} 0 \%, \mathrm{~K}_{1}=\mathrm{KNO}_{3} 1.5 \%, \mathrm{~K}_{2}=\mathrm{KNO}_{3} 2.0 \%$

Table.4 Effect of salicylic acid and potassium nitrate on stover yield (kg/ha) of lentil

\begin{tabular}{|c|c|c|c|c|c|}
\hline \multicolumn{2}{|c|}{ Treatment } & \multicolumn{3}{|c|}{ Potassium nitrate levels } & \multirow{3}{*}{$\begin{array}{c}\text { Mean S } \\
1,471.98\end{array}$} \\
\hline & & \multirow{2}{*}{$\begin{array}{c}\mathrm{K}_{0} \\
1,392.77\end{array}$} & \multirow{2}{*}{$\begin{array}{c}\mathrm{K}_{1} \\
1,540.88\end{array}$} & \multirow{2}{*}{$\begin{array}{c}\mathrm{K}_{2} \\
1,482.30\end{array}$} & \\
\hline \multirow{8}{*}{ 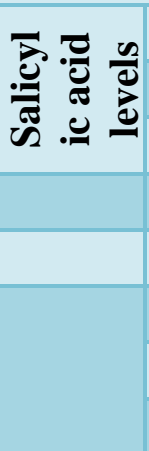 } & $\mathrm{S}_{0}$ & & & & \\
\hline & $\mathrm{S}_{1}$ & $1,561.55$ & $1,714.10$ & $1,647.75$ & $1,641.13$ \\
\hline & $\mathrm{S}_{2}$ & $1,598.88$ & $1,799.07$ & $1,746.66$ & $1,714.87$ \\
\hline & Mean K & $1,517.73$ & $1,684.68$ & $1,625.57$ & \\
\hline & & SEd $( \pm)$ & $\mathrm{CD}(\mathrm{P}=0.05)$ & & \\
\hline & Factor (S) & 19.54 & 40.56 & & \\
\hline & Factor $(\mathrm{K})$ & 19.54 & 40.56 & & \\
\hline & Factor $(\mathrm{S} \times \mathrm{K})$ & 33.84 & NS & & \\
\hline
\end{tabular}

$\mathrm{S}_{0}=0$ ppm Salicylic Acid, $\mathrm{S}_{1}=150 \mathrm{ppm}$ Salicylic Acid, $\mathrm{S}_{2}=200 \mathrm{ppm}$ Salicylic Acid, $\mathrm{K}_{0}=\mathrm{KNO}_{3} 0 \%, \mathrm{~K}_{1}=\mathrm{KNO}_{3} 1.5 \%, \mathrm{~K}_{2}=\mathrm{KNO}_{3} 2.0 \%$ 
Table.5 Effect of salicylic acid and potassium nitrate on biomass yield (kg/ha) of lentil

\begin{tabular}{|c|c|c|c|c|c|}
\hline \multicolumn{2}{|c|}{ Treatment } & \multicolumn{3}{|c|}{ Potassium nitrate levels } & \multirow{3}{*}{$\begin{array}{l}\text { Mean S } \\
2,256.78\end{array}$} \\
\hline & & $\mathrm{K}_{0}$ & $\mathrm{~K}_{1}$ & $\mathrm{~K}_{2}$ & \\
\hline \multirow{8}{*}{ 胥 } & $\mathrm{S}_{0}$ & $2,116.55$ & $2,362.18$ & $2,291.62$ & \\
\hline & $\mathrm{S}_{1}$ & $2,408.70$ & $2,661.03$ & $2,549.83$ & $2,539.85$ \\
\hline & $\mathrm{S}_{2}$ & $2,482.63$ & $2,903.95$ & $2,826.75$ & $2,737.77$ \\
\hline & Mean K & $2,335.96$ & $2,642.39$ & $2,556.06$ & \\
\hline & & $\operatorname{SEd}( \pm)$ & $\mathrm{CD}(\mathrm{P}=0.05)$ & & \\
\hline & Factor $(\mathrm{S})$ & 22.09 & 45.86 & & \\
\hline & Factor $(\mathrm{K})$ & 22.09 & 45.86 & & \\
\hline & Factor $(\mathrm{S} \times \mathrm{K})$ & 38.26 & 79.44 & & \\
\hline
\end{tabular}

$\mathrm{S}_{0}=0 \mathrm{ppm}$ Salicylic Acid, $\mathrm{S}_{1}=150 \mathrm{ppm}$ Salicylic Acid, $\mathrm{S}_{2}=200 \mathrm{ppm}$ Salicylic Acid, $\mathrm{K}_{0}=\mathrm{KNO}_{3} 0 \%, \mathrm{~K}_{1}=\mathrm{KNO}_{3} 1.5 \%, \mathrm{~K}_{2}=\mathrm{KNO}_{3} 2.0 \%$

Table.6 Effect of salicylic acid and potassium nitrate on harvest index (\%) of lentil

\begin{tabular}{|c|c|c|c|c|c|}
\hline \multicolumn{2}{|c|}{ Treatment } & \multicolumn{3}{|c|}{ Potassium nitrate levels } & \multirow{3}{*}{$\begin{array}{c}\text { Mean S } \\
34.79\end{array}$} \\
\hline & & $\mathrm{K}_{0}$ & $\mathrm{~K}_{1}$ & $\mathrm{~K}_{2}$ & \\
\hline \multirow{8}{*}{ 元 } & $\mathrm{S}_{0}$ & 34.22 & 34.80 & 35.35 & \\
\hline & $\mathrm{S}_{1}$ & 35.15 & 35.60 & 35.38 & 35.38 \\
\hline & $\mathrm{S}_{2}$ & 35.60 & 38.05 & 38.22 & 37.29 \\
\hline & Mean K & 34.99 & 36.15 & 36.32 & \\
\hline & & $\operatorname{SEd}( \pm)$ & $\mathrm{CD}(\mathrm{P}=0.05)$ & & \\
\hline & Factor $(\mathrm{S})$ & 0.43 & 0.89 & & \\
\hline & Factor $(\mathrm{K})$ & 0.43 & 0.89 & & \\
\hline & Factor $(\mathrm{S} \times \mathrm{K})$ & 0.74 & NS & & \\
\hline
\end{tabular}

$\mathrm{S}_{0}=0$ ppm Salicylic Acid, $\mathrm{S}_{1}=150 \mathrm{ppm}$ Salicylic Acid, $\mathrm{S}_{2}=200 \mathrm{ppm}$ Salicylic Acid, $\mathrm{K}_{0}=\mathrm{KNO}_{3} 0 \%, \mathrm{~K}_{1}=\mathrm{KNO}_{3} 1.5 \%, \mathrm{~K}_{2}=\mathrm{KNO}_{3} 2.0 \%$ 


\section{Test weight}

Irrespective of scaling up of SA up to 200 ppm and increasing the concentration of $\mathrm{KNO}_{3}$ up to $1.5 \%$ the test weight was found non-significant for both salicylic acid and potassium nitrate (Table 2). The test weight for the control plot was lowest as compared with the plots where seed priming was done with salicylic acid which recorded to be 20.79 g. The corresponding value for the plots where $200 \mathrm{ppm}$ of salicylic acid has been applied was $21.21 \mathrm{~g}$. The effect of potassium nitrate $\left(\mathrm{KNO}_{3}\right)$ on test weight for the control plot was lowest which recorded to be $20.97 \mathrm{~g}$. The corresponding values for the plots where $1.5 \%$ of potassium nitrate has been applied were $21.10 \mathrm{~g}$.

\section{Grain yield}

The grain yield of the lentil has been found to be lowest for control plot i.e. $\mathrm{S}_{0} \mathrm{~K}_{0}(723.78$ $\mathrm{kg} / \mathrm{ha}$ ) and highest for the treatment $\mathrm{S}_{2} \mathrm{~K}_{1}$ $(1104.98 \mathrm{~kg} / \mathrm{ha})$ which is $52.66 \%$ more than that of the control followed byS $\mathrm{S}_{2}$ and $\mathrm{S}_{1} \mathrm{~K}_{1}$ which are statistically at par (Table 3 ). The effect of salicylic acid and potassium nitrate on grain yield of lentil has been found to be significant both for individual and combined effects. Scaling up of SA up to $200 \mathrm{ppm}$ caused significant enhancement in yields of lentil. Similarly, increasing the concentration of $\mathrm{KNO}_{3}$ up to $1.5 \%$ led to marked improvement in yields of lentil. It was reported that application of SA has a positive effect in ameliorating the oxidative damages in plant and increase the yield. Similar findings were also corroborated by Devi et al., (2011) and Hossain et al., (2015). decrease grain yield under higher level of $\mathrm{KNO}_{3}$ might be due to the toxic effect of $\mathrm{KNO}_{3}$ at higher concentration. These findings are in consistency to those achieved by Singh et al., (2017). The interaction of SA and $\mathrm{KNO}_{3}$ is effective in improving the yield parameters under moisture stress conditions by delaying maturity due to enhancement of biochemical and physiological processes (Rhman and Attia, 2016).

\section{Stover yield}

The analysed data showed that the stover yield of the lentil has been found to be lowest for control plot i.e. $\mathrm{S}_{0} \mathrm{~K}_{0}(1561.55 \mathrm{~kg} / \mathrm{ha})$ and highest for the treatment $\mathrm{S}_{2} \mathrm{~K}_{1} \quad(1799.07$ $\mathrm{kg} / \mathrm{ha}$ ) which is $29.17 \%$ more than that of the control followed by $\mathrm{S}_{2} \mathrm{~K}_{2}$ and $\mathrm{S}_{1} \mathrm{~K}_{1}$ which are statistically at par (Table 4). The individual effect of salicylic acid and potassium nitrate on stover yield of lentil has been found to be significant but the combination effects has been found to be non-significant. Scaling up of SA up to $200 \mathrm{ppm}$ caused significant enhancement in yields of lentil. Similarly, increasing the concentration of $\mathrm{KNO}_{3}$ up to $1.5 \%$ led to marked improvement in yields of lentil. Increased in stover yield might be due to the growth promoting effect of SA which increased the level of cell division within the apical meristem of seedling root and caused higher plant growth and increased the dry matter production.

Similar findings were also corroborated by El-Hedek et al., (2013) and Ahmad et al., (2014). Increase in stover yield under decreasing level of $\mathrm{KNO}_{3}$ might be due to the toxic effect of $\mathrm{KNO}_{3}$ at higher concentration. This might be due to the foliar application of $\mathrm{KNO}_{3}$ which has positive effects of $\mathrm{N}$ and $\mathrm{K}$ at right time enhancing plant growth and dry matter accumulation. These findings are in consistency to those achieved by Nandakumar et al., (2004). Investigators indicated that potassium played a key role in the osmotic adjustment (stomatal opening) of plants under water stress and yield may be improved due to foliar potassium application to plants (Foyer et al., 2002). 


\section{Biomass yield}

The biomass yield of the lentil has been found to be lowest for control plot i.e. $\mathrm{S}_{0} \mathrm{~K}_{0}$ $(2116.55 \mathrm{~kg} / \mathrm{ha})$ and highest for the treatment $\mathrm{S}_{2} \mathrm{~K}_{1}(2903.95 \mathrm{~kg} / \mathrm{ha})$ which is $37.20 \%$ more than that of the control followed by $\mathrm{S}_{2} \mathrm{~K}_{2}$ and $\mathrm{S}_{1} \mathrm{~K}_{1}$ which are statistically at par (Table 5). The combined effect of salicylic acid and potassium nitrate on biomass yield of lentil has been found to be significant both for individual and combined effects. Scaling up of SA up to $200 \mathrm{ppm}$ caused significant enhancement in yields of lentil. Similarly, increasing the concentration of $\mathrm{KNO}_{3}$ up to $1.5 \%$ led to marked improvement in yields of lentil. This might be due to the cumulative effect of yield attributing characters and enhanced photosynthetic efficiency and greater diversion of assimilates towards reproductive organs. Similar findings were also reported by Farjam et al., (2014). Increase in biomass yield under decreasing level of $\mathrm{KNO}_{3}$ might be due to the toxic effect of $\mathrm{KNO}_{3}$ at higher concentration. Exogenous application of $\mathrm{KNO}_{3}$ might have a positive effect of $\mathrm{N}$ and $\mathrm{K}$ in increasing its dry matter synthesis and yield attributing characters during the course of development with higher partitioning efficiency. These findings are in consistency to those achieved by Khan et al., (2012).

\section{Harvest index}

Results showed that the harvest index of the lentil has been found to be lowest for control plot i.e. $\mathrm{S}_{0} \mathrm{~K}_{0}(34.22 \%)$ and highest for the treatment $\mathrm{S}_{2} \mathrm{~K}_{2}(38.21 \%)$ followed by $\mathrm{S}_{2} \mathrm{~K}_{1}$ and $\mathrm{S}_{2} \mathrm{~K}_{0}$ which are statistically at par (Table 6). The individual effect of salicylic acid and potassium nitrate on harvest index of lentil has been found to be significant but the combination effects has been found nonsignificant. Similarly, increasing the concentration of $\mathrm{KNO}_{3}$ up to $2.0 \%$ led to marked improvement in yields of lentil. This might be due the physiological index reflecting the percentage of assimilates mobilization from vegetative organs of plant into grains. Similar findings were also reported by Devi et al., (2011).Foliar application of $\mathrm{KNO}_{3}$ at optimum dose probably caused proportionately greater increase in economic part than the noneconomic parts, which might have resulted in higher harvest index. These findings are in consistency to those achieved by Duraisami and Mani (2002).

Based on the results from the experiment it can be concluded that seed priming of salicylic acid @200 ppm and foliar application of potassium nitrate @ $2.0 \%$ increases the growth attributes and salicylic acid@200 ppm and foliar application of potassium nitrate@ $1.5 \%$ increases the yield attributes, and ultimately yield of lentil.

\section{Acknowledgements}

The authors are thankful to Pandit Deen Dayal Upadhyay Institute of Agricultural Sciences, Utlou, Bishnupur District, Manipur, India and ICAR RC for NEH Region Manipur Centre for providing the facility and technical support to carry out this field experiment.

\section{References}

Abd-El-Rhman, I.E. and Attia, M.F. (2016) Foliar spray with potassium nitrate and salicylic acid for improving growth, yield and nutrients uptake by olive trees under salinity stress conditions. International Journal of Chem. Tech. Research. 9(12): 230-245.

Ali, E.A. and Mahmoud, A.M. (2013) Effect of foliar spray of different salicylic acid and zinc concentrations on seed yield and yield component of mungbean in sandy soil. Asian Journal of Crop 
Science. 5(1): 33-40.

Ahmad, I., Basra, S.M.A. and Wahid, A. (2014) Exogenous application of ascorbic acid, salicylic acid and hydrogen peroxide improves the productivity of hybrid maize at low temperature stress. International Journal of Agriculture and Biology.16 (4).

Bardhan, K., Kumar, V. and Dhimmar, S.K. (2007) An evaluation of the potentiality of exogenous osmoprotectants mitigating water stress on chickpea. The Journal of Agricultural Sciences. 3(2), $67-74$.

DOI: http://doi.org/10.4038/jas.v3i2.8101

Deotale, R.D., Mahale, S.A., Patil, S.R., Sahane, A.N. and Sawant, P.P. (2015) Effect of foliar sprays of nitrate salts on morphophysiological traits and yield of green gram. International Journal of Researches in Biosciences, Agriculture and Technology. 3(II) 63-67.

Devi, K.N., Vyas, A.K., Singh, M.S. and Singh, N.G. (2011) Effect of bioregulators on growth, yield and chemical constituents of soybean (Glycine max). Journal of Agricultural Science. 3(4) 151-159. doi.org/10.5539/jas.v3n4p151

Duraisami, V.P. and Mani, A.K. (2002) Yield maximization and economics in rice (Oryza sativa L.) grown during winter season under irrigated condition. Agriculture Update12, 403-408.

El-Hedek, K. S. (2013) Effect of foliar applications of salicylic acid and potassium silicate on tolerance of wheat plants to soil salinity. Journal of Soil Science and Agricultural Engineering. 4(3): 335-357.

Farahbakhsh, H. (2012) Germination and seedling growth in primed and primed seeds of fennel as affected by reduced water potential induced by $\mathrm{NaCl}$. International Research Journal of Applied Basic Science. 3, 737-44.
Farjam, S., Kazemi-Arbat, H., Siosemardeh, A., Yarnia, M. and Rokhzadi, A. (2014) Effects of salicylic and ascorbic acid applications on growth, yield, water use efficiency and some physiological traits of chickpea (Cicer arietinum L.) under reduced irrigation. Legume Research. 38(1): 66-71.

Foyer, C. H., Vanacker, H., Gomez, L. D. and Harbinson, J. (2002) Regulation of photosynthesis and antioxidant metabolism in maize leaves at optimal and chilling temperatures: review. Plant Physiology and Biochemistry.40, 659668.

Golezani, K.G., Jafari, S.F. and Kolvanagh, J.S. (2011) Seed priming and field performance of soybean (Glycine max L.) in response to water limitation. NotulaeBotanicaeHortiAgrobotanici.39( 2):186-189.

Gomez, K.A. and Gomez, A.A. (1984) Statistical procedures for agricultural research, John Wiley and Sons, Ink., New York.

Goud, V.V., Konde, N.M., Mohod, P.V. and Kharche, V.K. (2014) Response of chickpea to potassium fertilization on yield, quality, soil fertility and economic in vertisols. Legume Research. 37(3): 311-315.

Hayat, Q., Hayat, S., Alyemeni, M.N. and Ahmad, A. (2012) Salicylic acid mediated changes in growth, photosynthesis, nitrogen metabolism and antioxidant defense system in (Cicer arietinum L.).Plant soil environment.58(9): 417-423.

Hayat, Q., Hayat, S., Irfan, M. and Ahmad, A. (2010) Effect of expgenous salicylic acid under changing environment: A review. Environmental and Experimental Botany. 68, 14-25.

Hossain, M.I., Mannan, M.A. and Karim, M.A. (2015) Salicylic acid and gibberelic acid ameliorates the adverse 
effects of salinity on chickpea. Bangladesh Agronomy Journal. 18(1), 81-88.

Horvath, E., Szalai, S. and Janda, T. (2007) Induction of abiotic stress tolerance by salicylic acid signaling. Journal of Plant Growth Regulators. 26, 290-300.

Hsiao, T.C. and Lauchli, A. (1986) Role of potassiumin plant water relations. InTinker, B. and Lauchli, A. (eds.). Advances in Plant Nutrition.2, 281-312.

Imas, P. and Bansal, S.K. (2004) Use of MOP as fertilizer - some myths and reality. Fertilizer News. 49(11): 51-55.

Jabeen, N. and Ahmad, R. (2011) Foliar Application of Potassium Nitrate Affects the Growth and Nitrate Reductase Activity in Sunflower and Safflower Leaves under Salinity. Notulae Botanicae Horti Agrobotanici. 39(2): 172-178.

Jeyakumar, P., Velu, G., Rajendra, C., Amutha, R., Savery, M.A.J.R. and Chidambaram, S. (2008) Varied responses of blackgram (Vigna mungo) to certain foliar applied chemicals and plant growth regulators. Legume Research of International Journal. 31, 110-113.

Khan, A.W., Mann, R.A., Saleem, M. and Majeed, A. (2012) Comparative rice yield and economic advantage of foliar $\mathrm{KNO}_{3}$ over soil applied $\mathrm{K}_{2} \mathrm{SO}_{4}$. Pakistan Journal of Agricultural Sciences. 49(4): 481-484.

Khatun, S., Roy, T.S., Haque, M.N. and Alamgir, B. (2016) Effect of Plant Growth Regulators and Their Time of Application on Yield Attributes and Quality of Soybean. International Journal of Plant and Soil Science. 11(1): 1-9.

Korkmaz, A., Uzunlu, M. and Demirkiran, A.R. (2007) Treatment with acetyl salicylic acid protects muskmelon seedlings against drought stress.
ActaPhysiologiaePlantarum. 29， 503508.

Misra, N. and Saxena, P. (2009) Effect of salicylic acid on proline metabolism in lentil grown under salinity stress. Plant Science. 177, 181-189.

Muthulakshmi, S. and Lingakumar, K. (2016) Salicylic acid induced responses on growth and biochemical constituents in Vigna mungo (L.) hepper. European Journal of Experimental Biology. 6(1):9-14.

Msaakpa, T.S., Maiwa'azi, A.B., and Obasi, M.O. (2013) Responses of Cowpea to Growth Regulators on Nodulation and Yield. International Journal of Scientific and Research Publications.3(7): 1-5.

Nandakumar, R., Saravanan, A., Singaram, P. and Chandrasekaran, B. (2004) Effect of lignite humic acid on soil nutrient availability at different growth stages of rice grown on vertisols and alfisols. ActaAgronomica-Hungarica. 52(3): 227-235.

Raskin, I. 1992. Role of salicylic acid in plants. Annual Review of Plant Physiology and Plant Molecular Biology. 43, 439-463.

Raskin, I., Skubatz, H., Tang, W. and Mense, B.J.D. (1990) Salicylic acid levels in thermogenic and non thermogenic plants. Annals of Botany.66, 373-376.

Senaratna, T., Touchell, D., Bunn, E. and Dixon, K. (2000) Acetyl salicylic acid (Aspirin) and salicylic acid induce multiple stress tolerance in bean and tomato plants. Plant Growth Regulation. 30, 157-161.

Singh, C., Singh, P. and Singh R. (2011) Modern techniques of raising field crops. Second edition. Oxford and IBH Publishing Co. Pvt. Ltd.

Singh, H., Singh, M. and Kang, J.S. (2017) Effect of Potassium Nitrate on Yield and Yield Attributes of Spring Maize (Zea mays L.) under Different Dates of 
Planting. International Journal of Current Microbiology and Applied Sciences. 6 (3): 1581-1590.

Sujatha, K.B., (2001) Effect of foliar spray of chemicals and bioregulators on growth and yield of greengram (Vigna radiata L.). M. Sc. Thesis, Tamil Nadu Agric. Univ., Coimbatore.

Yadov, D.V. (2006) Potassium nutrition of sugarcane. In: Benbi DK et. al. (eds) Balanced fertilization for sustaining crop productivity. International Potash Institute, Horgen. Pp. 275- 288.
Yadav, R.K., Saini, P.K., Pratap, M. and Tripathi, S.K. (2018) Techniques of seed priming in field crops. International Journal of Chemical Studies. 6(3): 1588-1594.

Yildirim, E., Turan, M. and Guvenc, I. (2008) Effect of foliar salicylic acid applications on growth, chlorophyll and mineral content of cucumber (Cucumis sativus L.) grown under salt stress. Journal of Plant Nutrition. 31, 593-612.

\section{How to cite this article:}

Bibek Laishram, T. Basanta Singh, Athokpam Kalpana, Merinda Wangkheirakpam, Sunil Kumar Chongtham and Jiten Singh, W. 2020. Effect of Salicylic Acid and Potassium Nitrate on Growth and Yield of Lentil (Lens culinaris L.) under Rainfed Condition. Int.J.Curr.Microbiol.App.Sci. 9(11): 2779-2791. doi: https://doi.org/10.20546/ijcmas.2020.911.337 